\title{
INTERCROPPING AND N FERTILIZATION EFFECTS ON STRIGA INFESTATION, SOIL C AND N AND GRAIN YIELD OF MAIZE IN THE SOUTHERN GUINEA SAVANNA OF NIGERIA
}

\author{
Moses Samuel BASSEY ${ }^{1 *}$, Joy Ekaette ETOPOBONG ${ }^{1}$, Bigun Ishaku PONMAN ${ }^{2}$, \\ Sheriff Adam BADOM ${ }^{1}$, Aliyu USMAN ${ }^{1}$, Abubakar Kutigi MOHAMMED ${ }^{1}$, \\ Opeyemi Ruth IBRAHIM ${ }^{3}$ \\ ${ }^{1}$ National Cereals Research Institute, P.M.B. 8, Badeggi - Nigeria. \\ ${ }^{2}$ Department of Agricultural Engineering, Federal Polytechnic Bida - Nigeria. \\ ${ }^{3}$ National Biotechnology Development Agency, Ilori, Nigeria. \\ * Corresponding author. E-mail: mosessamuel36@yahoo.com
}

\begin{abstract}
Millions of hectares devoted to cereal production in Africa were affected by Striga infestation across locations and time. A study was conducted in 2012 and 2013 rainy seasons at the Teaching and Research Farms of Niger State College of Agriculture, Mokwa and the Teaching and Research Farms of Federal University of Technology, Minna, in the Southern Guinea Savanna ecology of Nigeria to determine cereal / legume intercropping and $\mathrm{N}$ fertilization effects on Striga infestation, Soil C and N and grain yield of maize. The treatments consisted of four inorganic $\mathrm{N}$ fertilizer levels $\left(0,60,90,120 \mathrm{~kg} \mathrm{ha}^{-1}\right)$, alternate hill and same hill intercropping of Aeschynomene histrix. Intercropping maize with A. histrix has the potential of reducing Striga parasitism with about $33-47 \%$ with respect to Striga shoots per $\mathrm{m}^{-2}$ and Striga shoots per plot thus, enhancing maize grain yield. The use of herbaceous legumes in intercropping contributed about 58\% SOC and 52-57\% reduction in number of S. hermonthica due to application of $\mathrm{N}$ using urea, thereby helping to control Striga infestation. Intercropping maize with $A$. histrix improved the soil organic matter and hence, the physical, chemical and biological properties of the soil for good crop growth. Incorporation of the A. histrix residues substantially increased the soil $\mathrm{N}$ content. There was response to inorganic $\mathrm{N}$ fertilizer application, suggesting the need for $\mathrm{N}$ application to maize for optimum grain yield. Nitrogen rate of $60 \mathrm{~kg} \mathrm{ha}^{-1}$ was optimum for maize yield in the study area.
\end{abstract}

Keywords: Grain yield, intercropping, legume, Maize, Striga infestation.

\section{Introduction}

Maize (Zea mays L.) ranks third globally after wheat and rice, provide $35 \%$ of food requirement in most countries and belongs to family Poaceae [BASSEY \& al. 2019a]. More than $50 \%$ of the total maize production is being used as a food in developing countries [ARUNKUMAR \& al. 2008]. Nigeria's corn (maize) production in 2019 (October-September) is about 10.5 MMT, two percent less than 10.7 million metric tons in 2018 estimates [AATF, 2011]. The phenomenal increase in maize production in Nigeria over the past few years was attributed to increase in its utilization for various food items, livestock feed and industrial materials, as well as research activities [FAO, 2009].

Intercropping (IC) is an ancient multiple-cropping system that is popular with smallholder farmers in developing countries today, due to its higher land and nutrient use efficiency [LI \& al. 2007], better economic returns [VAN ASTEN \& al. 2011], and lower pest and disease incidence [ZHU \& al. 2000] as compared to sole crops [HUANG \& al. 2019]. Numerous studies have been conducted on cereal / legume IC systems based on field experiments 
in Africa, Asia, Europe and Latin America [YU \& al. 2015; LI \& al. 2016; MARTIN-GUAY \& al. 2018]. These studies have shown that IC has yield advantages generated by the mechanisms of interspecific facilitation (or complementarity) and/or competitive production principles [ZHANG \& LI, 2003]. Due to facilitation and complementarity between species, cereal/legume IC has been widely practiced and promoted for sustainable agriculture development [ZHANG \& LI, 2003]. The use of intercropping of host crops with legume crops is to serve as trap crop. Leguminous trap- crops stimulate suicidal germination of Striga seeds and, therefore reduce the seed bank and improve soil fertility [SCHULTZ \& al. 2003]. KOLO \& LAWAL (2009) observed that sorghum interplanted with jointvetch (A. histrix) delayed Striga shoot emergence by about two weeks and reduced its density thus, increased the grain yield of the crop. DUGJE \& al. (2003) found that interplanting sorghum and millet with groundnut, respectively, reduced Striga infestation compared with sole cropping. Improved soil fertility conditions especially $\mathrm{N}$ is likely to lead to reduced Striga infestation. The use of herbaceous legumes can contribute to soil N, thereby helping to control Striga infestation. The yields benefit have been attributed to increased soil $\mathrm{N}$ availability following the legume through biological $\mathrm{N}$ fixation [YUSUF \& al. 2009a], mineralization of their residues and release of $\mathrm{N}$ from the breakdown of roots and nodules after harvest and higher soil organic carbon [YUSUF \& al. 2009b].

Striga hermonthica (Delile) Benth. (family Orobanchaceae)-is a debilitating root parasite and possesses an ominous obstacle to the African continent that is struggling with food security as it affects the livelihood of more than 300 million people [BABIKER, 2007]. Prodigious seed production, prolonged viability of the seeds and the subterranean nature of the early stages of parasitism make the control of the parasite by conventional methods difficult if not impossible. The increasing incidence of Striga has been attributed to poor soil fertility and structure, low soil moisture, intensification of land use through continuous cultivation and an expansion of cereal production [BERHANE, 2016]. Many potentially successful approaches developed to control this weed include using resistant/tolerant varieties, sowing clean seeds that are not contaminated with Striga seeds, rotating cereal hosts with trap crops that induce abortive germination of Striga seeds, intercropping, applying organic and inorganic soil amendments such as fertilizer or manure, fumigating soil with ethylene, applying post emergence herbicides, push-pull technology and using biological control agents [ABDALLAH \& al. 2015]. Based on some studies, the interaction of tied-ridging with $\mathrm{N}$ fertilizer and resistant varieties; cereal-legume intercropping and its interaction with $\mathrm{N}$ fertilizer revealed low Striga infestation. No single management option has been found effective across locations and time. AATF (2011) stated that Striga infests $40 \%$ of arable land in the African Savannah region and two - thirds of the 73 million hectares devoted to cereal production in Africa were affected by Striga. The hectarage of land under maize production infested by Striga was put at four million [ANON, 2011]. Nearly $100 \mathrm{~m}$ ha of the African Savanna is infested annually with the witchweed and more than half of African farmers recognize that Striga infestation is on the increase on their farms [EJETA, 2011]. Over US \$1billion losses per year was estimated for Striga infested maize alone in Africa [AATF, 2011]; a major cause of food insecurity in the region. In Nigeria based on an average grain loss of 39\% caused by S. hermonthica on sorghum, an estimated annual loss of US \$93.6 million was incurred [AATF, 2011].

The control of Striga has proved exceptionally difficult. In Nigeria, the use of inorganic fertilizers to increase the $\mathrm{N}$ content in the soil is not feasible for the peasant farmers due to lack of resources, inaccessibility, low industrial technology and poor road network, among others. One alternative to inorganic fertilizer to increase soil $\mathrm{N}$ is by intercropping with herbaceous legumes especially A. histrix or similar ones. Not many studies on the use of A. histrix which grows widely in Niger State, Nigeria, in the southern Guinea savanna have been done. Hence, 
the objectives of the study were to evaluate the effect of A. histrix on Striga infestation, soil organic carbon and nitrogen content, and maize yields.

\section{Materials and Methods}

Field experiments were conducted on a Striga infested field in 2012 and 2013 rainy seasons at the Teaching and Research Farms of Niger State College of Agriculture, Mokwa $\left(09^{\circ} 18^{\prime} \mathrm{N} ; 05^{\circ} 50^{\prime} \mathrm{E}\right)$ and the Teaching and Research Farms of Federal University of Technology, GidanKwano, Minna $\left(9^{\circ} 31.860^{\prime} \mathrm{N} ; 6^{\circ} 27.244^{\prime} \mathrm{E} ; 254 \mathrm{~m}\right)$, situated in the Southern Guinea savanna agro ecological zone of Nigeria. Rainfall pattern of both sites is monomodal with the rainy season in Minna starting in April or May and ending in October, while that of Mokwa start in March or April and end in October or November. Monthly rainfall during the period of study at both sites are shown in Table 1. The soil of the Minna site is with loamy sand surface soil texture, slightly acidic, low organic carbon, $\mathrm{N}$, and medium phosphorus. Selected soil physical and chemical properties of both sites before land preparation in 2012 are shown in Table 2. The two fields were heavily infested with Striga hermonthica which makes them to be sparingly cultivated with maize and sorghum over the years with no fertilizer.

Table 1. Monthly rainfall of the two experimental sites during the period of study

\begin{tabular}{lcccc}
\hline Months & Mokwa & Minna & $\begin{array}{c}\text { Rainfall (mm) } \\
\text { Mokwa }\end{array}$ & $\begin{array}{c}\text { Minna } \\
\mathbf{2 0 1 3}\end{array}$ \\
\hline January & \multicolumn{2012}{c}{} & 0.0 & 0.0 & 0.0 \\
February & 58.0 & 1.5 & 0.0 & 0.0 \\
March & 0.0 & 0.0 & 20.1 & 0.0 \\
April & 88.0 & 258.0 & 43.4 & 34.2 \\
May & 235.4 & 140.4 & 165.0 & 204.5 \\
June & 123.0 & 67.3 & 174.0 & 96.5 \\
July & 268.2 & 194.7 & 346.0 & 333.1 \\
August & 132.0 & 160.4 & 423.2 & 376.9 \\
September & 111.4 & 301.8 & 487.0 & 337.2 \\
October & 38.0 & 100.3 & 76.3 & 158.0 \\
November & 0.0 & 0.0 & 12.1 & 0.0 \\
December & 0.0 & 0.0 & 0.0 & 0.0 \\
Total annual rainfall & 1054 & 1224.4 & 1747.1 & 1540.4 \\
\hline
\end{tabular}

Source: College of Agriculture metrological station 
Table 2. Some soil physical and chemical properties of both sites before planting in 2012

\begin{tabular}{|c|c|c|}
\hline \multirow[b]{2}{*}{ Properties } & \multicolumn{2}{|c|}{ Values } \\
\hline & Mokwa & Minna \\
\hline Sand $\left(\mathrm{g} \mathrm{kg}^{-1}\right)$ & 795 & 860 \\
\hline Silt $\left(\mathrm{g} \mathrm{kg}^{-1}\right)$ & 116 & 93 \\
\hline Clay $\left(\mathrm{g} \mathrm{kg}^{-1}\right)$ & 89 & 47 \\
\hline Textural class & Loamy sand & Loamy sand \\
\hline $\mathrm{pH}\left(\mathrm{H}_{2} \mathrm{O}\right)\left(\mathrm{g} \mathrm{kg}^{-1}\right)$ & 6.7 & 6.8 \\
\hline Organic Carbon $\left(\mathrm{g} \mathrm{kg}^{-1}\right)$ & 3.30 & 2.39 \\
\hline Total Nitrogen $\left(\mathrm{g} \mathrm{kg}^{-1}\right)$ & 1.80 & 0.15 \\
\hline Available Phosphorus $\left(\mathrm{mg} \mathrm{kg}^{-1}\right)$ & 18 & 12 \\
\hline $\mathrm{Na}+\left(\mathrm{cmol} \mathrm{kg}^{-1}\right)$ & 0.09 & 0.23 \\
\hline $\mathrm{K}+\left(\mathrm{cmol} \mathrm{kg}^{-1}\right)$ & 0.19 & 0.36 \\
\hline $\mathrm{Mg}++\left(\mathrm{cmol} \mathrm{kg}^{-1}\right)$ & 0.98 & 1.65 \\
\hline $\mathrm{Ca}++\left(\mathrm{cmol} \mathrm{kg}^{-1}\right)$ & 4.96 & 2.77 \\
\hline Exchangeable acidity $\left(\mathrm{cmol} \mathrm{kg}^{-1}\right)$ & 0.11 & 0.04 \\
\hline $\operatorname{ECEC~}\left(\mathrm{cmol} \mathrm{kg}^{-1}\right)$ & 6.32 & 5.05 \\
\hline
\end{tabular}

\section{Treatments and experimental design}

The two sites had the same treatments, experimental designs and plot sizes. The treatments were four inorganic $\mathrm{N}$ fertilizer levels $\left(0,60,90,120 \mathrm{~kg} \mathrm{ha}^{-1}\right)$, alternate hill and same hill intercropping of $A$. histrix. The treatments were laid out in a randomized complete block design with three replicates. There were 18 experimental plots, such that gross plot size was 8 $\mathrm{m} \times 4 \mathrm{~m}\left(32 \mathrm{~m}^{2}\right)$ and the net plot size was $18 \mathrm{~m}^{2}$, separated by $1 \mathrm{~m}$ alley. The number of ridges in the plot was five while the length of ridge was $8 \mathrm{~m}$.

Both sites have the same crop establishment and management. The fields were manually cleared and ridged using hoe at $75 \mathrm{~cm}$ apart in 2012 and 2013 . The maize variety, SUWAN 1, obtained from premier seeds, highly susceptible to Striga was manually planted at 3 seeds per hill, spaced $50 \mathrm{~cm}$ within rows. The seedlings were thinned to two plants per hill at two weeks after sowing (WAS) to give a plant population of 53, 3333 plants ha ${ }^{-1}$. Basal application of $30 \mathrm{~kg} \mathrm{P} \mathrm{ha}^{-1}$ as single superphosphate and $30 \mathrm{~kg} \mathrm{~K} \mathrm{ha}^{-1}$ as muriate of potash were carried out at $2 \mathrm{WAS}$ after thinning. Inorganic $\mathrm{N}$ fertilizer as urea was split - applied to plots that were to receive $\mathrm{N}$ fertilizer. At 2 WAS, one-third of the $\mathrm{N}$ was applied, while the remaining two-third were applied at 6 WAS. Fertilizers were applied by side banding at about $5 \mathrm{~cm}$ away from the seedlings and at about $5 \mathrm{~cm}$ deep along the ridge. The first hoe - weeding was carried out at 3 WAS while the second weeding was at 5 WAS followed by careful hand-pulling of weeds other than Striga.

\section{Data collection}

The data collected from both sites were the same. The number of Striga shoots per maize plant was taken by counting each Striga shoot present per maize plant stand starting from 6 WAS. The number of Striga shoots flowering was taken by counting closely the number that flowered in each plot. The number of Striga shoots per meter squared was taken by counting closely the number of Striga present in each plot per $\mathrm{m}^{2}$. Days to $50 \%$ Striga shoot flowering was carried out by counting the number of days from the day the first Striga shoot emerged to the day that $50 \%$ of 
Striga shoots flowered. The Striga reaction score was taken on the scale of 0-9 using visual observation to measure mild, severe and very severe or death infestation of Striga on maize plant.

Ten maize plants from each of the net plot were randomly tagged for periodic observation at 3, 6 and 9 WAS. The following observations made were: The maize plant population was carried out by counting individual plants at 3,6 and 9 WAS. This is also known as plant population count and expressed in hectare. The maize plant height was observed by tagging ten plants from the inner rows at random which were used throughout for taking the measurements. The plant height was measured using meter rule from the top of the uppermost leaf to the base of the plant at 3 and 6 WAS but from the base to the tip of the tassel at 9 WAS and expressed in centimeters. Days to $50 \%$ maize tasseling was taken through observation by counting the number of days from the sowing date to the day when about $50 \%$ of all the maize plants in each plot has tasseled and expressed in percentage. The average cob length of 10 harvested tagged maize plant from the inner row of each plot were taken and measured using meter rule and expressed in centimeters. The number of maize cobs from the inner rows of each plot was counted and estimated per hectare. This was done when the plant attains physiological maturity. The number of maize grain per cob was also obtained by weighing those harvested from the inner rows and shelled at harvest time. This was done by counting. 100 maize grain weights was taken from the ten harvested cobs from each plot, shelled and weighed using a weighing balance, expressed in grams. The maize grain yield analysis was carried out by harvesting maize ears in the two central rows leaving out the border plants at both ends (net plot of $18 \mathrm{~m}^{2}$ ). These were shelled, air- dried and weighed. The grain yield was adjusted to $12 \%$ moisture content for each plot and weighed.

Soil samples were taken at harvest from each treatment plot and subjected to routine analyses. Particle size analysis was done by the hydrometer method [KLUTE, 1986], organic matter was determined by the procedure of Walkley and Black using the dichromate wet oxidation method [NELSON \& SOMMERS, 1982]. Total $\mathrm{N}$ was determined by the micro Kjeldahl digestion method [BREMNER \& MULVANEY, 1982] and available P was by Bray 1extraction followed by molybdenum blue colourimetry [BREMNER \& MULVANEY, 1982]. Exchangeable K, Ca and Mg was extracted by EDTA titration method [THOMAS, 1982]. Soil $\mathrm{pH}$ was determined in 1:2 soil-water ratio using digital electronic $\mathrm{pH}$ meter.

\section{Data analysis}

The data collected were subjected to analysis of variance (ANOVA) and means were separated using Duncan Multiple Range Test at 5\% level of probability. The statistical package used was Statistical Analysis System (SAS), version 9.2 (2002).

\section{Results}

The effect of intercropping and $\mathrm{N}$ fertilization on Striga shoot $\mathrm{m}^{-2}$ was significant (Table 3). In 2012 at Mokwa site, AH intercropping had the least Striga shoot at 9 WAS while the zero $\mathrm{N}$ application had the highest. However, the effect of $60-120 \mathrm{~kg} \mathrm{~N}$ ha $^{-1}$ fertilizer application and SH intercropping on Striga shoot were similar. Also, at 12 WAS in Mokwa site, SH and AH intercropping had the least Striga shoot which were similar, and the effects of 60$120 \mathrm{~kg} \mathrm{~N} \mathrm{ha}^{-1}$ fertilizer application and intercropping treatments on Striga shoot were not significantly different. In 2013, AH intercropping had the least Striga shoot at both sites at 9 WAS while zero $\mathrm{N}$ application had the highest. However, the effect of 0-90 kg N ha-1 application on Striga shoot were similar at both sites. In the same year at 12 WAS, at Minna site, AH had the least Striga shoot while zero N application had the highest. However, application of 0-120 
$\mathrm{kg} \mathrm{N} \mathrm{ha}^{-1}$ fertilizer on Striga shoot were similar at Mokwa, while at Minna site, application of 60-120 $\mathrm{kg} \mathrm{ha}^{-1}$ fertilizer and SH intercropping had similar effects on number of Striga hoots.

Table 3. Effect of intercropping and $\mathrm{N}$ fertilization on Striga shoot $\mathrm{m}^{-2}$ at 9 and $12 \mathrm{WAS}$ in 2012 and 2013 cropping seasons

\begin{tabular}{|c|c|c|c|c|c|c|c|c|}
\hline \multirow[t]{3}{*}{ Treatment } & \multicolumn{8}{|c|}{ Striga shoot $\mathbf{m}^{-2}$} \\
\hline & Mokwa & Minna & Mokwa & Minna & Mokwa & Minna & Mokwa & Minna \\
\hline & \multicolumn{2}{|c|}{$\begin{array}{l}9 \text { WAS } \\
2012\end{array}$} & \multicolumn{2}{|c|}{$\begin{array}{l}12 \text { WAS } \\
2012\end{array}$} & \multicolumn{2}{|c|}{$\begin{array}{l}9 \text { WAS } \\
2013\end{array}$} & \multicolumn{2}{|c|}{$\begin{array}{l}12 \text { WAS } \\
2013\end{array}$} \\
\hline $0 \mathrm{~kg} \mathrm{~N} \mathrm{ha}^{-1}$ & $3 a$ & $17 \mathrm{a}$ & $6 a$ & $11 \mathrm{a}$ & $6 a$ & $14 \mathrm{a}$ & $12 \mathrm{a}$ & $44 a$ \\
\hline $60 \mathrm{~kg} \mathrm{~N} \mathrm{ha}^{-1}$ & $2 \mathrm{ab}$ & $16 \mathrm{a}$ & $5 \mathrm{ab}$ & $11 \mathrm{a}$ & $2 \mathrm{ab}$ & $10 \mathrm{a}$ & $11 \mathrm{a}$ & $30 \mathrm{~b}$ \\
\hline $90 \mathrm{~kg} \mathrm{~N} \mathrm{ha}^{-1}$ & $1 b$ & $11 \mathrm{a}$ & $2 \mathrm{ab}$ & $11 \mathrm{a}$ & $2 a b$ & $8 a$ & $8 \mathrm{ab}$ & $30 \mathrm{~b}$ \\
\hline $120 \mathrm{~kg} \mathrm{~N} \mathrm{ha}^{-1}$ & $1 b$ & $9 \mathrm{a}$ & $2 \mathrm{ab}$ & $10 \mathrm{a}$ & $1 b$ & $8 \mathrm{a}$ & $8 \mathrm{ab}$ & $29 b$ \\
\hline SH & $1 b$ & $8 \mathrm{a}$ & $1 b$ & $10 \mathrm{a}$ & $1 b$ & $5 b$ & $6 \mathrm{~b}$ & $29 b$ \\
\hline $\mathrm{AH}$ & $0 \mathrm{c}$ & $8 \mathrm{a}$ & $1 b$ & $8 \mathrm{a}$ & $0 \mathrm{c}$ & $0 \mathrm{c}$ & $4 b$ & $22 c$ \\
\hline $\mathrm{SE} \pm$ & 0.30 & 1.01 & 0.70 & 1.03 & 0.50 & 1.02 & 1.20 & 3.03 \\
\hline
\end{tabular}

Means in the column with different letter(s) are significantly different from each other at $\mathrm{P}<0.05$ using Duncan Multiple Range Test (DMRT). WAS - Weeks after planting, SH - Same hill, AH - Alternate hill, SE - Standard error.

The effect of intercropping and $\mathrm{N}$ fertilization on Striga shoot growing with maize was significant (Table 4). In 2012 at Mokwa site, SH and AH intercropping had the least number of Striga shoot growing with maize while zero $\mathrm{N}$ fertilizer had the highest number of shoots. However, the effect of 60-120 kg N ha-1 fertilizer application, and SH and AH intercropping on Striga shoot were similar. Zero N fertilization had the highest Striga shoot at 12 WAS while 60 to $120 \mathrm{~kg} \mathrm{~N} \mathrm{ha}^{-1}$ and intercropping treatments had the lowest. In 2013, AH intercropping had the least Striga shoot at Mokwa site at 9 WAS which were similar to $120 \mathrm{~kg} \mathrm{~N} \mathrm{ha}^{-1}$ and SH intercropping. In the same year, at $12 \mathrm{WAS}$, AH had the least Striga shoot at Minna site while zero $\mathrm{N}$ fertilizer had the highest number of shoots.

Table 4. Effect of intercropping and $\mathrm{N}$ fertilization on Striga shoots growing with maize plant at 9 and 12 WAS in 2012 and 2013 cropping seasons

\begin{tabular}{|c|c|c|c|c|c|c|c|c|}
\hline \multirow[t]{3}{*}{ Treatment } & \multicolumn{8}{|c|}{ Striga shoot per maize plant } \\
\hline & Mokwa & Minna & Mokwa & Minna & Mokwa & Minna & Mokwa & Minna \\
\hline & \multicolumn{2}{|c|}{$\begin{array}{c}9 \text { WAS } \\
2012 \\
\end{array}$} & \multicolumn{2}{|c|}{$\begin{array}{c}12 \text { WAS } \\
2012 \\
\end{array}$} & \multicolumn{2}{|c|}{$\begin{array}{c}9 \text { WAS } \\
2013 \\
\end{array}$} & \multicolumn{2}{|c|}{$\begin{array}{c}12 \text { WAS } \\
2013 \\
\end{array}$} \\
\hline $0 \mathrm{~kg} \mathrm{~N} \mathrm{ha}^{-1}$ & $7 \mathrm{a}$ & $20 \mathrm{a}$ & $15 \mathrm{a}$ & $29 a$ & $3 a$ & $29 a$ & $4 \mathrm{a}$ & $124 \mathrm{a}$ \\
\hline $60 \mathrm{~kg} \mathrm{~N} \mathrm{ha}^{-1}$ & $3 a b$ & $19 \mathrm{a}$ & $3 b$ & $28 \mathrm{a}$ & $2 \mathrm{ab}$ & $27 \mathrm{a}$ & $4 a$ & $93 a$ \\
\hline $90 \mathrm{~kg} \mathrm{~N} \mathrm{ha}^{-1}$ & $2 b$ & $19 \mathrm{a}$ & $2 b$ & $26 \mathrm{a}$ & $2 \mathrm{ab}$ & $25 \mathrm{a}$ & $3 a$ & $74 a$ \\
\hline $120 \mathrm{~kg} \mathrm{~N} \mathrm{ha}^{-1}$ & $1 b$ & $18 \mathrm{a}$ & $1 b$ & $25 \mathrm{a}$ & $1 b c$ & $22 \mathrm{a}$ & $3 a$ & $66 \mathrm{a}$ \\
\hline $\mathrm{SH}$ & $0 \mathrm{~b}$ & $13 \mathrm{a}$ & $1 b$ & $22 \mathrm{a}$ & $1 b c$ & $22 \mathrm{a}$ & $3 a$ & $60 b$ \\
\hline $\mathrm{AH}$ & $0 \mathrm{~b}$ & $12 \mathrm{a}$ & $1 b$ & $20 \mathrm{a}$ & $0 \mathrm{c}$ & $19 \mathrm{a}$ & $3 a$ & $45 c$ \\
\hline $\mathrm{SE} \pm$ & 0.81 & 3.00 & 1.88 & 2.01 & 0.33 & 2.03 & 0.25 & 7.04 \\
\hline
\end{tabular}

Means in the column with different letter(s) are significantly different from each other at $\mathrm{P}<0.05$ using Duncan Multiple Range Test (DMRT). WAS - Weeks after planting, SH - Same hill, AH - Alternate hill, SE - Standard error. 
Moses Samuel BASSEY \& al.

The effect of intercropping and $\mathrm{N}$ fertilization on Soil $\mathrm{C}$ and $\mathrm{N}$ was significant (Table 5). In 2012 at both sites, $\mathrm{AH}$ intercropping had the highest Soil $\mathrm{C}$ while zero $\mathrm{N}$ application had the lowest. However, the effects of SH intercropping and $\mathrm{N}$ fertilization treatments at Minna site, and 60-90 $\mathrm{kg} \mathrm{N} \mathrm{ha}^{-1}$ fertilizer application and $\mathrm{AH}$ intercropping were similar in Soil $\mathrm{C}$. In the same manner, SH intercropping had the highest soil C at both sites in 2013 while zero $\mathrm{N}$ application had the lowest. Soil $\mathrm{N}$ was significantly higher in $\mathrm{AH}$ intercropping than the $\mathrm{N}$ fertilization treatments in 2012. However, the effects of SH intercropping and $\mathrm{N}$ fertilization treatments were similar in Soil N.

Table 5. Effect of intercropping and $\mathrm{N}$ fertilization on Soil $\mathrm{C}$ and $\mathrm{N}$ at physiological maturity of maize in 2012 and 2013 cropping seasons

\begin{tabular}{|c|c|c|c|c|c|c|c|c|}
\hline \multirow{3}{*}{ Treatment } & \multicolumn{4}{|c|}{ Soil C $\left(\mathrm{g} \mathrm{kg}^{-1}\right)$} & \multicolumn{4}{|c|}{ Soil N $\left(\mathrm{g} \mathrm{kg}^{-1}\right)$} \\
\hline & \multirow{2}{*}{\multicolumn{2}{|c|}{2012}} & Mokwa & Minna & Mokwa & Minna & Mokwa & Minna \\
\hline & & & \multicolumn{2}{|c|}{2013} & \multicolumn{2}{|c|}{2012} & \multicolumn{2}{|c|}{2013} \\
\hline $0 \mathrm{~kg} \mathrm{~N} \mathrm{ha}^{-1}$ & $3.18 \mathrm{~b}$ & $2.39 \mathrm{~b}$ & $5.80 \mathrm{ab}$ & $3.21 \mathrm{~b}$ & $1.08 \mathrm{~b}$ & $0.15 b$ & $1.12 \mathrm{a}$ & $0.12 \mathrm{a}$ \\
\hline $60 \mathrm{~kg} \mathrm{~N} \mathrm{ha}^{-1}$ & $3.73 \mathrm{ab}$ & $2.41 \mathrm{~b}$ & $6.23 \mathrm{ab}$ & $3.23 b$ & $1.05 \mathrm{~b}$ & $0.17 \mathrm{~b}$ & $1.16 \mathrm{a}$ & $0.16 \mathrm{a}$ \\
\hline $90 \mathrm{~kg} \mathrm{~N} \mathrm{ha}^{-1}$ & $3.63 \mathrm{ab}$ & $2.44 \mathrm{~b}$ & $5.13 b$ & $3.36 \mathrm{~b}$ & $1.08 \mathrm{~b}$ & $0.19 \mathrm{~b}$ & $1.12 \mathrm{a}$ & $0.12 \mathrm{a}$ \\
\hline $120 \mathrm{~kg} \mathrm{~N} \mathrm{ha}^{-1}$ & $2.97 \mathrm{~b}$ & $2.45 b$ & $4.97 \mathrm{~b}$ & $3.37 \mathrm{~b}$ & $1.07 \mathrm{~b}$ & $0.18 \mathrm{~b}$ & $1.19 \mathrm{a}$ & $0.19 \mathrm{a}$ \\
\hline SH & $3.05 \mathrm{~b}$ & $2.47 \mathrm{~b}$ & $6.67 \mathrm{a}$ & $3.45 \mathrm{a}$ & $1.11 \mathrm{~b}$ & $0.19 \mathrm{~b}$ & $1.12 \mathrm{a}$ & $0.12 \mathrm{a}$ \\
\hline $\mathrm{AH}$ & $4.78 \mathrm{a}$ & $2.53 \mathrm{a}$ & $5.27 \mathrm{~b}$ & $3.39 \mathrm{~b}$ & $1.85 \mathrm{a}$ & $0.24 \mathrm{a}$ & $1.15 \mathrm{a}$ & $0.15 \mathrm{a}$ \\
\hline $\mathrm{SE} \pm$ & 0.20 & 0.02 & 0.02 & 0.01 & 0.01 & 0.02 & 0.01 & 0.01 \\
\hline
\end{tabular}

Means in the column with different letter(s) are significantly different from each other at $\mathrm{P}<0.05$ using Duncan Multiple Range Test (DMRT). SH - Same hill, AH - Alternate hill, SE - Standard error.

The effect of intercropping and $\mathrm{N}$ fertilization on grain yield was significant (Table 6). In 2012 and 2013 at both sites, application of $60 \mathrm{~kg} \mathrm{~N} \mathrm{ha}^{-1}$ produced the highest maize grain yield than the higher rates of $\mathrm{N}$ fertilization and intercropping treatments. However, in 2012 at Mokwa site, the effect of 60-120 kg N ha-1 fertilizer application and $\mathrm{AH}$ intercropping on maize grain yield were similar. In the same manner, at Minna site in 2013 , the effect of $60 \mathrm{~kg} \mathrm{~N} \mathrm{ha}^{-1}$ fertilizer application and $\mathrm{AH}$ intercropping on maize grain yield were similar.

Table 6. Effect of intercropping and N fertilization on Grain yield of maize in 2012 and 2013 cropping

\begin{tabular}{lcccc}
\hline \multicolumn{5}{c}{ seasons } \\
Treatment & Mokwa & Minna & $\begin{array}{c}\text { Grain yield (kg ha-1) } \\
\text { Mokwa }\end{array}$ & Minna \\
\hline $0 \mathrm{~kg} \mathrm{~N} \mathrm{ha}^{-1}$ & $1306 \mathrm{c}$ & $1207 \mathrm{e}$ & $2222 \mathrm{~d}$ & $1804 \mathrm{e}$ \\
$60 \mathrm{~kg} \mathrm{~N} \mathrm{ha}^{-1}$ & $1757 \mathrm{a}$ & $1590 \mathrm{a}$ & $3505 \mathrm{a}$ & $3034 \mathrm{a}$ \\
$90 \mathrm{~kg} \mathrm{~N} \mathrm{ha}^{-1}$ & $1628 \mathrm{ab}$ & $1436 \mathrm{~b}$ & $3131 \mathrm{bc}$ & $2567 \mathrm{~b}$ \\
$120 \mathrm{~kg} \mathrm{~N} \mathrm{ha}^{-1}$ & $1539 \mathrm{ab}$ & $1442 \mathrm{~b}$ & $2587 \mathrm{~cd}$ & $1890 \mathrm{~d}$ \\
$\mathrm{SH}$ & $1412 \mathrm{bc}$ & $1385 \mathrm{c}$ & $2616 \mathrm{c}$ & $2117 \mathrm{c}$ \\
$\mathrm{AH}$ & $1552 \mathrm{ab}$ & $1368 \mathrm{~d}$ & $3295 \mathrm{~b}$ & $3010 \mathrm{ab}$ \\
$\mathrm{SE} \pm$ & 5.10 & 4.2 & 1.60 & 1.42 \\
\hline
\end{tabular}

Means in the column with different letter(s) are significantly different from each other at $\mathrm{P}<0.05$ using Duncan Multiple Range Test (DMRT). SH - Same hill, AH - Alternate hill, SE - Standard error. 


\section{Discussion}

Striga shoots per $\mathrm{m}^{-2}$ and Striga shoot per maize plant were generally reduced by and varied between $\mathrm{N}$ fertilization and $A$. histrix intercropping with maize in this study. This clearly demonstrated that alternate plants of $A$. histrix could cause a reduction in Striga emergence, similar to application of $\mathrm{N}$ at $60-120 \mathrm{~kg} \mathrm{~N} \mathrm{ha}^{-1}$. Furthermore, same hill intercropping of $A$. histrix also produced a reduction in Striga shoots in this study. These might be attributed to A. histrix acting as a trap or catch crop and the shading effect from A. histrix canopy. In addition to shading out Striga in intercropping systems, the A. histrix has also shown to stimulate the germination of Striga without acting as host, just like cowpea and soybean. Our findings is in agreement with various studies that shown that intercropping cereals, mainly with legumes such as cowpea (Vigna unguiculata), peanut (Arachis hypogaea) and green gram (Vigna radiata) can reduce the number of Striga plants [CARSKY \& al. 2000; BASSEY \& al. 2019a]. Potentially, they might be acting as traps crops, stimulating suicidal Striga germination or the microclimate under the crop canopy may be altered and interfere with Striga germination and development [KUREH \& al. 2000]. It is also hypothesized that nitrogen fixed by the legumes might interact with Striga growth, as increasing the amount of available nitrogen can reduce Striga densities [KUCHINDA \& al. 2003; BASSEY \& al. 2019b]. Our findings in this studies show that $52-57 \%$ reduction in number of $S$. hermonthica recorded was due to application of $\mathrm{N}$ using urea. This is because the nitrogenous compound fertilizer which contains urea considerably suppressed germination of $S$. hermonthica when applied during conditioning. It could also be because the germination of $S$. hermonthica seed is associated with the secretion of germination stimulants by host plants. The secretion ultimately depends upon the nutrient status of the soil. Our findings is in agreement with [BASSEY \& al. 2019c], who reported 55-82\% reduction in number and weight of $S$. hermonthica due to application of $\mathrm{N}$ using urea in Niger. BERHANE (2016) also reported that $\mathrm{N}$ fertilizers altered assimilate partitioning in favour of the ear and increased maize grain yield and reduced Striga count by $64 \%$. Similarly, the study of ABDALLAH \& al. (2015) conducted in North east Nigeria showed a reduction in Striga infestation and damage with the application of $\mathrm{N}$ fertilizer on maize varieties.

The soil organic carbon (SOC) and soil total nitrogen (STN) were increased by intercropping. The findings of this experiment indicated that $A$. histrix fixed about $5 \%$ SOC. This can be attributed to the high $\mathrm{C} / \mathrm{N}$ ratio of the $A$. histrix residue which ensure a slow rate of mineralization of the residue, with consequent increase in SOC. There was also significant effect of intercropping and $\mathrm{N}$ fertilization on soil total nitrogen (STN), although there was a slight decrease across all the treatment. This scenario might be due to high STN in the organic form, which was not immediately available for crop use. The significant effects of intercropping and $\mathrm{N}$ fertilization on SOC and STN at physiological maturity might be due to dead leaves and roots added to the soil. The immobilization of $\mathrm{N}$ as a result of the high $\mathrm{C} / \mathrm{N}$ ratio of the residues could be responsible for the high STN. Intercropping and $\mathrm{N}$ fertilization had positive effects on SOC and STN at physiological maturity of maize. Our finding was in agreement with those of CRICK (2007) and BASSEY \& al. (2019b), who noted an appreciable increase in soil fertility in crop mixture, involving certain tropical legumes after cropping. They adduced the increase in soil fertility to the ability of legumes to fix large quantities of nitrogen into the soil. The inclusion of legumes in many crop mixtures had been reported to include improvement in $\mathrm{N}$ status of the soil through nitrogen fixation, its short lifespan, as well as its ability to cover the ground, with resultant decreases in the incidence of weed infestation and soil erosion [AYA, 2004; GERH, 2007]. The inclusion of certain tropical legumes in crop mixture has been reported to increase soil organic carbon, total nitrogen, available phosphorus and exchangeable potassium. In addition to the above, the inclusion of legumes in crop associations minimizes the risk 
Moses Samuel BASSEY \& al.

of crop failure and brings about higher total returns per unit area of land which allows larger financial gains for farmers [BEADER, 2004]. Significant effects of increasing maize planting density in a cowpea/maize mixture on soil nutrients and cowpea yield have been demonstrated by many studies [EZEMADU, 2007; VINE, 2007].

Maize grain yield was increased but varied between $\mathrm{N}$ fertilizer levels and A. histrix intercropping with maize in this study. The positive response (increase) observed in this study for grain yield due to $\mathrm{N}$ application and intercropping with A. histrix could probably be due to incorporation of residues resulting in high SOC and legume root system turnover. Increase in soil organic matter level might have resulted in increase in soil fertility, nutrient supply, porosity, permeability and thus, soil productivity [GRAY \& MORANT, 2003; BASSEY \& al. 2019b]. Our findings obtained are consistent with that of other workers in the same savanna agroecological zone of Nigeria [YUSUF \& al. 2009a]. FRANKOW-LINDBERG \& DAHLIN (2013) have suggested that a major part of the legume root system turnover occurs in the uppermost part of the soil profile. In a study in coastal lowland Kenya, SAHA (2015) observed the highest maize root length density in the top $30 \mathrm{~cm}$ of the soil profile. Therefore, intercropped maize is likely to benefit from the root system turnover of cowpea planted within the same row. Grain yield without inorganic $\mathrm{N}$ fertilizer was significantly lower than that of the other inorganic $\mathrm{N}$ levels. Similar response to inorganic $\mathrm{N}$ fertilizer has been reported in the study area by ADEBOYE \& al. (2009) and AFOLABI \& al. (2017). The high yield obtained in the study area might also be attributed to reduced temperature and moisture conservation effected by the overlapping maize and legume canopies. Nutrient uptake is known to increase with improved soil moisture. Maize intercropped with legume within the row probably responded to soil moisture conservation by increasing its nutrient uptake, leading to increased yields [TENEBE \& PETU-IBIKUNLE, 2012].

\section{Conclusion}

From the results of this study, it can be concluded that intercropping maize with $A$. histrix has the potential of reducing Striga parasitism with respect to Striga shoots per $\mathrm{m}^{-2}$ and Striga shoots per plot thus, enhancing maize grain yield. The use of herbaceous legumes in intercropping contributed to soil $\mathrm{N}$, thereby helping to control Striga infestation. Striga infestation is frequently associated with low soil fertility. Intercropping maize with $A$. histrix improved the soil organic matter and hence, the physical, chemical and biological properties of the soil for good crop growth. Incorporation of the A. histrix residues substantially increased the soil $\mathrm{N}$ content. There was response to inorganic $\mathrm{N}$ fertilizer application, suggesting the need for $\mathrm{N}$ application to maize for optimum grain yield. Nitrogen rate of $60 \mathrm{~kg} \mathrm{ha}^{-1}$ was optimum for maize yield.

\section{Notes on contributors}

Moses Samuel BASSEY is a plant protectionist with special interest in weed science and agronomy. His focus is on the Striga management practices and Maize productivity. Joy Ekaette ETOPOBONG is a soil scientist with special interest in soil fertility. Bigun PONMAN Ishaku is a crop scientist with special interest in crop agronomy. Sheriff Adam BADOM is a research extension scientist with special interest in result dissemination. Aliyu USMAN is a crop scientist with special interest in crop agronomy. Abubakar Kutigi MOHAMMED is a plant breeder with special interest in crop improvement. Opeyemi Ruth IBRAHIM is a research scientist at National Biotechnology Development Agency. 


\section{Acknowledgement}

We want to use this medium to acknowledge and to thank the management of National Cereals

Research Institute for the support in providing all that was needed for the execution of this work.

\section{References}

AATF (African Agricultural Technology Foundation). 2011. Feasibility study on Striga control in Sorghum. African Agricultural Technology Foundation, Nairobi: ISBN 9966775-12-9.

ABDALLAH B., SAHA H. M. \& TSANUO M. K. 2015. Integrating Striga resistant maize and spatial arrangement of intercropped cowpea in the control of Striga asiatica. International Journal of Agronomy and Agricultural Research. 7(6): 25-33.

ADEBOYE M. K. A., OSUNDE A. O., TSADO P. A., ODOFIN J. A., BALA A. \& ADEYEMI R. A. 2009. Response of maize grain yields to rates and split application of nitrogen and NPK combinations in the southern Guinea savanna of Nigeria. Journal of Agriculture and Agricultural Technology. 2(1): 108-118.

AFOLABI S. G., ADEBOYE M. K. A., LAWAL B. A., BASSEY M. S. \& USMAN A. 2017. Cereal / legume rotation effects on soil carbon and nitrogen and grain yield of maize in the southern guinea savanna of Nigeria. Nigerian Journal of Soil Science. 27(7): 12-20.

ANON. 2011. Researchers and farmers begin effort to reduce crop loss from Striga attack in Africa. http:Ilwww.spipm.cgiarorg|newslblogs|513633. Accessed 10 $0^{\text {th }}$ June, 2011.

ARUN-KUMAR M. A., GAIL S. K. \& HEBSUR N. S. 2008. Effect of different levels of NPK on growth and yield parameters of sweet corn. Karnatak Journal of Agricultural Science. 20: 41-43.

AYA K. O. 2004. Effects of increasing maize population in a soybean/maize mixture on soil nutrients and performance of soybean. Agriculture Science Journal. 5(3): 405-409.

BABIKER A. G. T. 2007. Striga: The Spreading Scourge in Africa. Regular Plant Growth and Development. 42: 74-87.

BASSEY M. S., IBRAHIM P. A., MOHAMMED A. K., MUSA I., HADIZA A. B. \& NGONADI E. N. 2019a. Maize/Jointvelch intercropping and $\mathrm{N}$ fertilization effects on Striga infestation and maize grain yield in the Southern Guinea Savanna of Nigeria. International Journal of Environment, Agriculture and Biotechnology. 4(4): $1-9$.

BASSEY M. S., ADEBOYE M. K. A. \& KOLO M. G. M. 2019b. Effects of fallowing and nitrogen application on Striga infestation, soil fertility and maize performance. International Journal of Plant and Soil. 27(3): 1-10. https://doi.org/10.9734/ijpss/2019/v27i330076

BASSEY M. S., OLANIYAN O. B., ONOTUGOMA E., SHERIFF A. B. \& ONWUEGBA M. C. 2019c. Effects of fallowing and nitrogen application on Striga infestation and maize performance. International Journal of Applied Research and Technology. 8(4): 9-16.

BEADER F. M. 2004. Biological and economic appraisal of the productivity of cowpea - based intercropping systems. Crop Ecology. 3(1): 176-181.

BERHANE S. 2016. Review on Striga Weed Management. International Journal of Life Science and Scientific Research. 2(2): 110-120.

BREMNER J. M. \& MULVANEY C. S. 1982. Nitrogen-total. In: PAGE A. L., MILLER R. H. \& KEENEY D. R. (eds.). Methods of soil analysis. Part II. Chemical and microbiological Properties. American Society of Agronomy, Madison, Wisconsin: 643-698.

CARSKY R. J., BERNER D. K., OYEWOLE B. D., SHIELL K. D. A. \& SCHULZ S. 2000. Reduction of Striga hermonthica parasitism on maize using soybean rotation. Journal of Pest Management. 40(2): 115-120.

CRICK A. 2007. Effects of the inclusion of certain tropical legumes in crop mixtures on soil fertility. Soil Science. 4 : 411-415.

DUGJE I. Y., ODO P. E. \& JOSHUA S. D. 2003. Effect of planting pattern and variety of pearl millet intercropped with groundnut on Striga infestation on the Nigeria Sudan savanna. Nigerian Journal of Weed Science. 16: 39-46.

EJETA G. 2011. The Striga scourge in Africa. A growing pandemic. In: HAUSSINANN B. I. G., HESS D. E., KOYAMA M. L., GRIVETI L., RATTUNDE H. F. W. \& GEIGER H. H. (eds.). Integrating new technologies for Striga control - Towards ending the witch-hunt. World Scientific Publishing Co Plc: 5-9.

EZEMADU V. O. 2007. Influence of cowpea - based intercropping systems on soil nutrient dynamics. Advanced Journal of Soil Science Research. 10: 991-996.

FOOD AND AGRICULTURAL ORGANISATION, FAO. 2009. www.statistic@ fao.org.htp:Ilfao.org.

FRANKOW-LINDBERG B. E \& DAHLIN A. S. 2013. N2 fixation, N transfer, and yield in grassland communities including a deep-rooted legume or nonlegume species. Plant and Soil. 370: 567-581. https://doi.org/10.1007/s11104-013-1650-z 
GERH S. S. 2007. The role of certain tropical legumes in improving and maintaining soil organic matter. Soil Science Research. 3(3): 666-671.

GRAY L. C. \& MORANT P. 2003. Reconciling indigenous knowledge with scientific assessment of soil fertility changes in south western Burkina Faso. Geoderma. 111: 425-437. https://doi.org/10.1016/S0016-7061(02)00275-6

HUANG C., LIU Q., LI X. \& ZHANG C. 2019. Effect of intercropping on maize grain yield and yield components. Journal of Integrative Agriculture. 18(8): 1690-1700. https://doi.org/10.1016/S2095-3119(19)62648-1

KLUTE A. 1986. Methods of Soil Analysis. No. 9. Part 2. Physical and Mineralogical Properties. American Society of Agronomy, Madison, Wisconsin.

KOLO M. G. M \& LAWAL M. 2009. Interplanting of sorghum (Sorghum bicolor (L.) Moench.) with Aeschynomene histrix (Poir.) for the control of witch weed (Striga hermenthica (Del.) Benth.). Proceedings of the $43^{\text {rd }}$ Annual Conference of the Agricultural Society of Nigeria, Abuja, 20-23 October, 2009: 201-205.

KUCHINDA N. C., KUREH I., TARFA B. D., SHINGGU C. \& OMOLEHIN R. 2003. On farm evaluation of improved maize varieties intercropped with some legumes in the control of Striga in the northern Guinea Savanna of Nigeria. Crop Protection. 22: 533-538. https://doi.org/10.1016/S0261-2194(02)00206-5

KUREH I., CHIEZEY U. F. \& TARFA B. D. 2000. On station verification of the use of the soybeans trap - crop for the control of Striga in maize. African Crop Science Journal. 8(3): 295-300. https://doi.org/10.4314/acsj.v8i3.27694

LI L., LI S. M., SUN J. H., ZHOU L. L., BAO X. G., ZHANG H. G. \& ZHANG F. S. 2007. Diversity enhances agricultural productivity via rhizosphere phosphorus facilitation on phosphorus-deficient soils. Proceedings of the National Academy of Sciences of the United States of America. 104: 11192-11196.

LI Q. S., WU L. K., CHEN J., KHAN M. A., LUO X. M. \& LIN W. X. 2016. Biochemical and microbial properties of rhizospheres under maize/peanut intercropping. Journal of Integrative Agriculture. 15(1): 101-110. https://doi.org/10.1016/S2095-3119(15)61089-9

MARTIN-GUAY M. O., PAQUETTE A., DUPRAS J. \& RIVEST D. 2018. The new Green Revolution: sustainable intensification of agriculture by intercropping. Science of the Total Environment. 615: 767-772. https://doi.org/10.1016/j.scitotenv.2017.10.024

NELSON D. W. \& SOMMERS L. E. 1982. Total carbon, organic carbon and organic matter. In: PAGE A. L., MILLER R. H. \& KEENEY D. R. (eds). Methods of soil analysis. No. 9, Part 2. Chemical and Mineralogical Properties. American Society of Agronomy, Madison, Wisconsin, USA.

SAHA H. M. 2015. Resource use under maize-green manure legume intercropping systems. LAMBERT Academic Publishing: 69-83.

SCHULTZ S., HUSSAINI M. A., KLING J. G., BERNER D. K. \& IKIE F. O. 2003. Evaluation of integrated Striga hermonthica control technologies under farmer management. Experimental Agriculture. 39: 99-108. https://doi.org/10.1017/S0014479702001084

TENEBE V. A. \& PETU-IBIKUNLE A. M. 2012. Manageable agronomic practices in organic production of cowpea (Vigna unguiculata) in a mixed culture with sorghum. Journal of Crop Production. 1: 12-18.

THOMAS G. W. 1982. Exchangeable cations. In: PAGE A. L., MILLER R. H. \& KEENEY D. R. (eds). Methods of soil analysis. Part 2. Chemical and Microbiological Properties. American Society of Agronomy, Madison, Wisconsin: 159-164.

VAN ASTEN P. J. A., WAIREGI L. W. I., MUKASA D. \& URINGI N. O. 2011. Agronomic and economic benefits of coffee-banana intercropping in Uganda's smallholder farming systems. Agricultural Systems. 104(4): 326-334. https://doi.org/10.1016/j.agsy.2010.12.004

VINE F. R. 2007. Effects of increasing guinea corn population in a cowpea/guinea corn mixture on soil nutrients and performance of guinea corn in northern Nigeria. Journal of Agricultural Research. 6(3): 403-408.

YU Y., STOMPH T. J., MAKOWSKI D. \& VAN DER WERF W. 2015. Temporal niche differentiation increases the land equivalent ratio of annual intercrops: a meta-analysis. Field Crops Research. 184: 133-144. https://doi.org/10.1016/j.fcr.2015.09.010

YUSUF A. A., ABAIDOO R. C., IWUAFOR E. N. O., OLUFAJO O. O. \& SANGINGA N. 2009a. Rotation effects of grain legumes and fallow on maize yield, microbial biomass and chemical properties of an Alfisol in the Nigerian savanna. Agriculture, Ecosystem and Environment. 129(1-3): 325-331. https://doi.org/10.1016/j.agee.2008.10.007

YUSUF A. A., IWUAFOR E. N. O., ABAIDOO R. C., OLUFAJO O. O. \& SANGINGA N. 2009b. Grain legume rotation benefits to maize in the northern Guinea savanna of Nigeria: Fixed-nitrogen versus other rotation effects. Nutrient Cycling in Agroecosystem. 84: 129-139. https://doi.org/10.1007/s10705-008-9232-9

ZHANG F. \& LI L. 2003. Using competitive and facilitative interactions in intercropping systems enhances crop productivity and nutrient-use efficiency. Plant and Soil. 248: 305-312. https://doi.org/10.1023/A:1022352229863 
ZHU Y., CHEN H., FAN J., WANG Y., LI Y., CHEN J., FAN J., YANG S., HU L., LEUNG H., MEW T. W., TENG P. S., WANG. Z. \& MUNDT C. C. 2000. Genetic diversity and disease control in rice. Nature. 406: 718722. https://doi.org/10.1038/35021046

How to cite this article:

BASSEY M. S., ETOPOBONG J. E., PONMAN B. I., BADOM S. A., USMAN A., MOHAMMED A. K. \& IBRAHIM O. R. 2021. Intercropping and N fertilization effects on Striga infestation, soil C and N and grain yield of maize in the Southern Guinea Savanna of Nigeria. J. Plant Develop. 28: 97-108. https://doi.org/10.47743/jpd.2021.28.1.876 